\title{
An Archaeological Survey and Monitoring of the Razing of the Acuna Furniture and Music Company Building, Downtown San Antonio, Texas
}

I. Waynne Cox

Follow this and additional works at: https://scholarworks.sfasu.edu/ita

Part of the American Material Culture Commons, Archaeological Anthropology Commons, Environmental Studies Commons, Other American Studies Commons, Other Arts and Humanities Commons, Other History of Art, Architecture, and Archaeology Commons, and the United States History Commons

Tell us how this article helped you.

This Article is brought to you for free and open access by the Center for Regional Heritage Research at SFA ScholarWorks. It has been accepted for inclusion in Index of Texas Archaeology: Open Access Gray Literature from the Lone Star State by an authorized editor of SFA ScholarWorks. For more information, please contact cdsscholarworks@sfasu.edu. 


\section{An Archaeological Survey and Monitoring of the Razing of the Acuna Furniture and Music Company Building, Downtown San Antonio, Texas}

\section{Creative Commons License}

\section{(c) (1) \&}

This work is licensed under a Creative Commons Attribution-NonCommercial 4.0 International License 
AN ARCHAEOLOGICAL SURVEY AND MONITORING OF THE RAZING OF THE ACUNA FURNITURE AND MUSIC COMPANY BUILDING, DOWNTOWN SAN ANTONIO, TEXAS

I. Waynne Cox

Center for Archaeological Research The University of Texas at San Antonio ${ }^{\circ}$ Archaeological Survey Report, No. 157 



\section{ABSTRACT}

In September 1985, the Center for Archaeological Research, The University of Texas at San Antonio, was requested to conduct an investigation of the archaeological potential of the Acuña Furniture and Music Company building located at 125 North Flores Street, San Antonio, Texas. An archival search, to determine the construction period of the present building and possible prior structures, was conducted, and an on-site inspection was made. Both indicated that no historic resources would be affected by the demolition of the building. The demolition of the building was monitored to assure that no artifacts were revealed. No further work is recommended at this time. 
TABLE OF CONTENTS

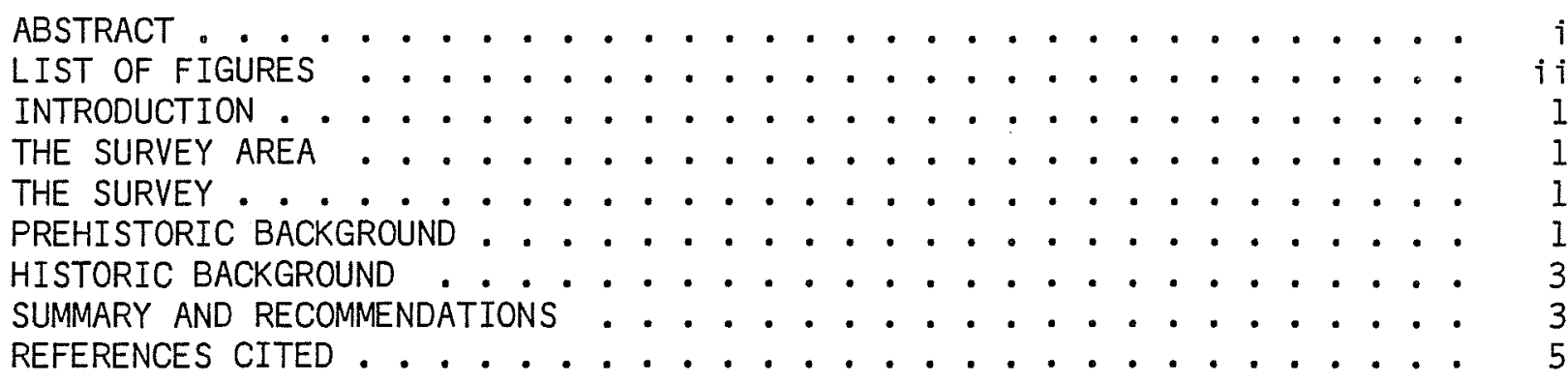

LIST OF FIGURES

1. Location of Acuña Furniture and Music Company Building on NCB 122 .

2. Villa and Presidio of San Antonio de Bexar in 1767 . . . . . . 
INTRODUCTION

The inspection and monitoring of the destruction of the Acuña Furniture and Music Company building was carried out by the Center for Archaeological Research (CAR), The University of Texas at San Antonio (UTSA), from September 5 to October 4, 1985. The work was conducted under a contract between the CAR-UTSA and Frost National Bank, San Antonio, Texas. Although the Acuña building was not a historic structure, the monitoring of the demolition of the building was requested because of its location within the Main and Military Plaza Historic District, and the work was done in compliance with the National Historic Preservation Act of 1966, as amended, and Executive Order 11593.

The field work and research were conducted by Waynne Cox, CAR research associate, under the supervision of Thomas R. Hester, CAR director and principal investigator, and Jack D. Eaton, CAR associate director.

\section{THE SURVEY AREA}

The building that previously housed the Acuña Furniture and Music Company occupied the central east side of New City B1ock (NCB) 122, Lot 6 on the street frontage at 125 North Flores Street, San Antonio, Texas. The block is bounded on the north by Houston Street (formerly Rivas Street), on the east by Flores Street (formerly $\mathrm{Ca} 11 \mathrm{le}$ Rea1), on the south by Commerce Street (formerly Presidio Street), and on the west by Camaron Street (formerly Aamargura Street; Fig. 1). The building was surrounded on three sides by the paved lot of Frost Motor Bank number 2. NCB 122 is the first block north of the historic Military Plaza and the city hall of San Antonio.

\section{THE SURVEY}

On September 5, 1985, the author accompanied by Mr. Larry Black, senior vice president, Frost National Bank, inspected the former Acuña Furniture and Music Company building. The structure had been vacated at a prior date. The basement, which occupied approximately the rear one-third of the building, was examined and found to be of modern construction. No evidence of any prior construction was found. The razing of the building was 1 ater monitored by the author. The building was demolished, and the debris was deposited in the basement area. No subsurface excavations were made.

\section{PREHISTORIC BACKGROUND}

While there are several reported prehistoric sites in the downtown San Antonio area, for example Brackenridge Park (41 BX 13) and the Incarnate Word Co1 lege campus (41 BX 24), there has been only one site (4I BX 25) reported near Main and Military Plaza (Schuetz 1966). This site was 1ocated at the intersection of St. Mary's and Market Streets, the location of the present San Antonio Main Public Library. The site was revealed as a badly disturbed deposit of both prehistoric and historic occupations. Probabiy the 1 ack of 


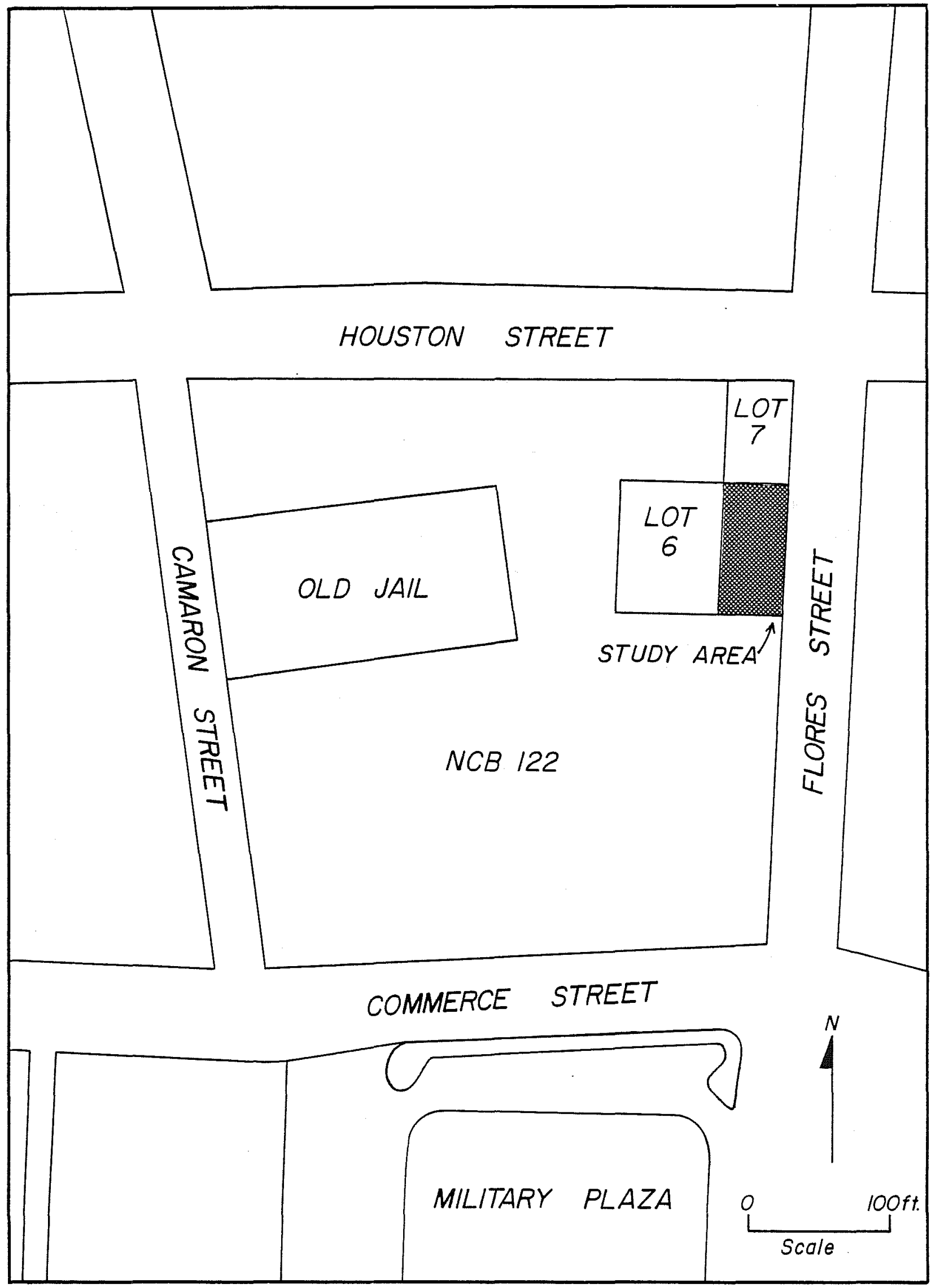

Figure 1. Location of Acuña Furniture and Music Company Building on NCB 122. Lots 6 and 7 are indicated. 
identified sites is due to the long intensive occupation of this area from 1719 and continuing to the present.

\section{HISTORIC BACKGROUND}

The Vi 11 a and Presidio of San Antonio de Béxar were founded on the present site of Military Plaza in 1722 by the Marques de Aguayo (Webb 1952:541). In March 1731, with the arrival of the colonists from the Canary Islands, the Villa of San Fernando de Bexar was establ ished at the Plaza de 1 as Islas, now Main Plaza (Webb 1952:550). The 1 ands in the vicinity were distributed to the new arrivals for their homes and farms.

The 1 and, which is now NCB 122, Lot 6, was originally granted to Manuel Fuentes, a soldier, by the Spanish government in 1761 (Spanish Archives Vol. 2:462). By 1767, two smal1 structures had been erected on the property (Fig. 2; Urrutia 1767). On November 2, 1825, the 1 and was transferred by Doña Ana Marfa Fuentes, Manuel's daughter, to Mariano Seguin, who in turn conveyed it to Juan José Maria Erasmo de Jeslis Seguin in December 1831.

Erasmo Seguin sold the northern half of the lot to Auguste Fretelliere in November 1851 (BCDR Vol. J1:78). Fretelliere constructed a two-story stone house on the site prior to 1852 (BCDR Vol. Pl:583; City Survey Book 1853 Vol 1:188). The house was 1 ater occupied by Judge Isaiah Addison Paschal and his wife, Mary, unti1 1854 (Chabot 1937:317). The southern half of the 1 ot was conveyed by Mariana Leal Dwyer to Francis Guilbeau in June 1859 (BCDR Vol. F2:31). Guilbeau had previously purchased the lot to the south from Seguin in 1847 (BCDR Vo1. F2:31).

By 1877, the Fretel1 iere house had become the Adams boarding house and remained such until its destruction in about 1905 (Sanborn Map and Publishing Company, Ltd. 1877; City Directories 1896-1905). Later, the 1ot was occupied by a stable owned by Jack Stotts until about 1913. In 1920, a one-story fireproof building was erected on both portions of the lot which was occupied by several smal1 businesses. In 1958, the modern building for the Acuña Furniture Company was constructed (City Directories 1905-1975).

The block to the north (Lot 7, NCB 122) was the site of the famous Buckhorn Saloon from 1921 until its destruction in 1957. Its renowned collections are now owned by the Lone Star Brewery. At the time of the demolition of that building, remnants of the San Pedro Acequia were encountered and investigated.

\section{SUMMARY AND RECOMMENDATIONS}

No archaeological artifacts or historic substructures were revealed by the demolition of the Acuña Furniture and Music Company building. No further work is recommended at this time because the paving of the lot will seal in and protect any cultural resources that may be in this area. However, since the basement area was confined to the back one-third of the building, the front portion facing on Flores Street still holds the potential of containing valuable archaeological or historical information. Therefore, if any 


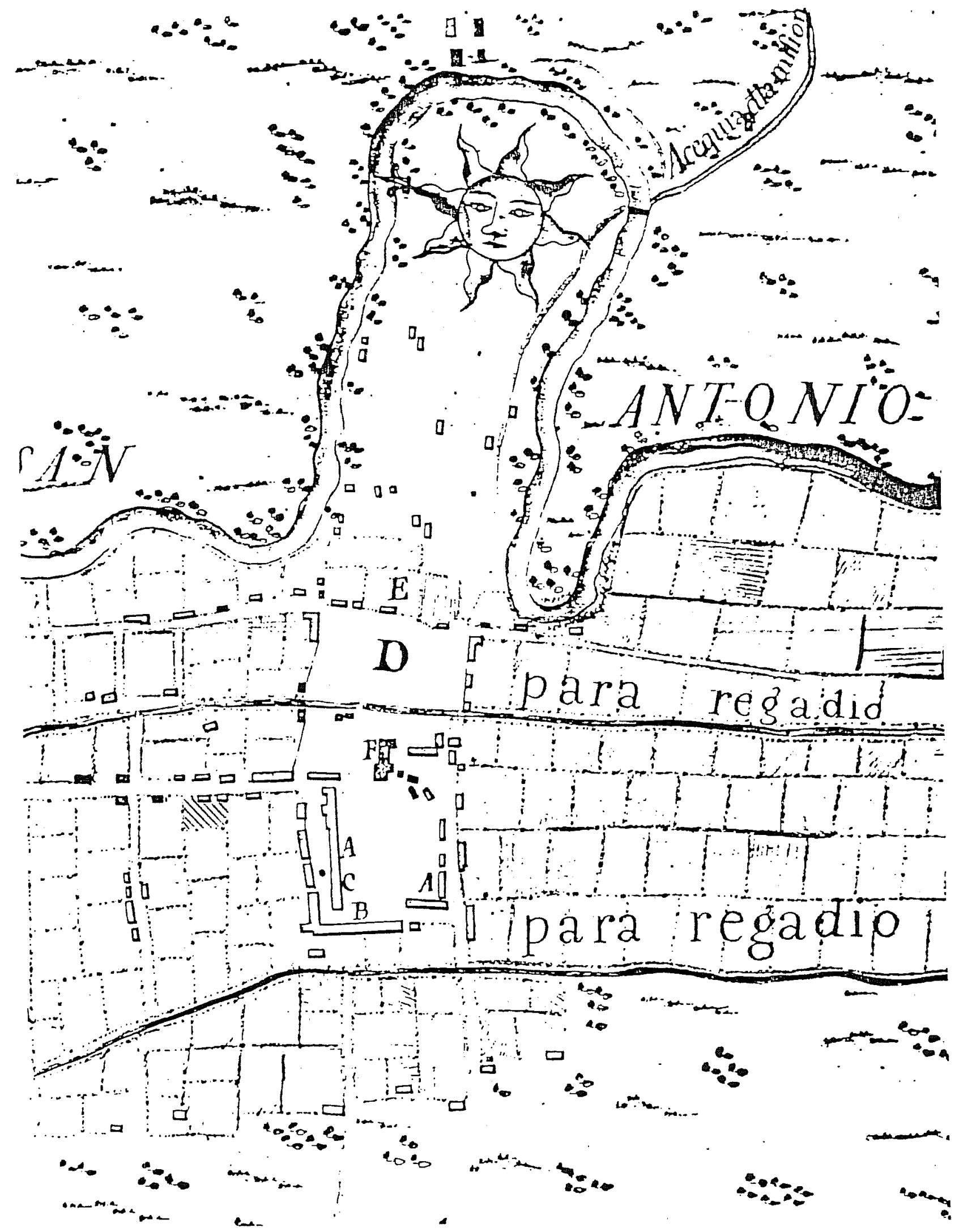

Figure 2. Villa and Presidio of San Antonio de Béxar in 1767. From Urrutia (1767). 
subsurface excavations are to be conducted in this area, an archaeological investigation should be conducted prior to such action.

\section{REFERENCES CITED}

Bexar County, Texas

Bexar County Deed Records (BCDR)

Originals and microfi $1 \mathrm{~m}$ in the Bexar County Courthouse, San Antonio, Texas.

Chabot, F. C.

1937 With the Makers of San Antonio. Artes Graficas, San Antonio, Texas.

City of San Antonio, Texas

1853 City Survey Book. Volume 1. City Engineers Office, City Ha11, San Antonio, Texas.

1896- City Directories. Daughters of the Repub 1 ic of Texas Research 1975 Library at the A1amo, San Antonio, Texas.

\section{Sanborn Map and Publishing Company, Ltd.}

1877 Map of San Antonio, Texas. Sheet 1. Copy at the Center for Archaeological Research. The University of Texas at San Antonio.

Schuetz, M. R.

1966 Unpublished site report on file at the Witte Museum, San Antonio, Texas.

\section{Spanish Archives}

3 volumes. Translations in the General Land Office, Austin, Texas.

Urrutia, Joseph de

1767 Vil1 a and Presidio of San Antonio de Bexar in 1767, copied from a photographic enlargement in the Library of the San Antonio Conservation Society. Original in the Department of Manuscripts, The British Library, London.

Webb, W. P., editor

1952 The Handbook of Texas. Volume II. The Texas State Historical Association, Austin, Texas. 
